\title{
Protest and Discipline: Shostakovich and the Revolutionary Self
}

\author{
C. H.M. Kelly
}

For citation: Kelly C.H.M. Protest and Discipline: Shostakovich and the Revolutionary Self. Vestnik of Saint Petersburg University. History, 2018, vol. 63, issue 4, pp. 1132-1155. https://doi. org/10.21638/11701/spbu02.2018.409

This article returns to the topic of Shostakovich's political views, and specifically, his response to the revolutions of 1917. It argues that the view of Shostakovich as certainly neutral if not positively dissident is coloured by the assumptions of the post-Stalin era and the views current at the time of what constituted principled behaviour. If we return to primary documents (e.g. Shostakovich's autobiographical questionnaire or his correspondence), the standpoint is much more elusive, and also heavily nuanced by genre and addressee. The main purpose of the article, however, is to look in detail at what it meant for Shostakovich to experience the revolutions at an extremely young age (only 9). Context for this is provided in an important collection of children's autobiographies collected by the émigré charitable association, Zemgor, in 1923-1924. These texts, written in an atmosphere that did not require the expression of revolutionary solidarity (as comparable Soviet autobiographies did), and which was even positively hostile to this, nevertheless often record the euphoria as well as terror that the events of 1917 inspired. A further frame for Shostakovich's later personal development was his exposure to a contradictory and conflicted educational process. The schooling that he received at the Shidlovskaya College, a Montessori-inspired free school, stood in radical contrast to the harsh discipline and regimentation of his education at the Conservatoire, a conflict that also helps to explain some of the cognitive dissonance of his later years.

Keywords: Shostakovich, the history of childhood in Russia, personal development in the early $20^{\text {th }}$ century, history of culture, history of education.

\section{Протест и дисциплина: Шостакович и революционная субъективность}

\section{К. Келли}

Для цитирования: Kelly C.H.M. Protest and Discipline: Shostakovich and the Revolutionary Self // Вестник Санкт-Петербургского университета. История. 2018. Т. 63. Вып. 4. С. 1132-1155. https://doi.org/ 10.21638/11701/spbu02.2018.409

Catriona Kelly - D. Phil, Professor, University of Oxford, New College, Hollywell Str., Oxford, OX13BN, UK; catriona.kelly@new.ox.ac.uk

Катриона Келли - D. Phil, проф., Оксфордский университет, Великобритания, OX1 3BN, Оксфорд, Нью Колледж, Холливелл стрит; catriona.kelly@new.ox.ac.uk

The project Childhood in Russia, 1890-1991: A Social and Cultural History was supported by the Leverhulme Trust

The author would like to thank participants in the conference "Schostakowitsch: Handgranat eines Anarchisten" at the Hochschule Luzern, 2013, Professor Philip Ross Bullock, Dr Rosamund Bartlett, and the two anonymous readers at Vestnik of Saint-Petersburg University. History for their useful comments and suggestions on earlier versions of this text. My thanks also to the staffs of the Bodleian Library, University of Oxford, Russian National Library, and the Russian State Historical Archive (RGIA) for their help.

(c) Санкт-Петербургский государственный университет, 2018 
В данной статье автор возвращается к вопросу о политических взглядах Д.Шостаковича и его восприятии революций 1917 г. Автор доказывает, что представление о Шостаковиче как о политически нейтральном, отчужденном наблюдателе исторических событий и советского строя восходит к послесталинскому времени и продиктовано характерными для данного периода «шестидесятническими» представлениями о «порядочном человеке». Документы 1920-х годов - переписка, «Анкеты» и т. д. - представляют гораздо более сложную и запутанную картину, сильно нюансированную вопросами жанра и адресата. Более того, биографические исследования Шостаковича практически не уделяют внимания психологическому контексту, а прежде всего тому очевидному факту, что революционные события Шостакович видел в 9-летнем возрасте. Богатые материалы проекта собирания детских автобиографий, проведенный эмигрантской ассоциацией Земгор в 1923-1924 гг., позволяют реконструировать характерную для детского наблюдателя смесь восторга и страха, имеющую значение и для психологического развития Шостаковича. Другой очень важный фрейм для понятия личности композитора - его школьные годы, в частности влияние на детское сознание идей «свободного воспитания». С помощью неопубликованных документов из архива училища М.Шидловской, в которых подробно описываются школьная программа и методология преподавания, вырисовывается воспитательное учреждение с идеалами, идущими вразрез с жесткой дисциплиной и муштровкой, характерными для консерватории в годы учебы Шостаковича. Как считает автор, эта двойственность биографических впечатлений имела большое значение для амбивалентного восприятия революционных событий и идеалов раннесоветского периода композитором и в более позднее время, уже в зрелые годы.

Ключевые слова: Д. Шостакович, история детства в России, развитие личности в начале $\mathrm{XX}$ в., история культуры, история образования.

One of the odd paradoxes in the secondary literature on Shostakovich is that discussion of the composer's life and work is at one level obsessed with the relationship between this individual figure and history, yet addresses the historical background to the composer's life in a highly selective way. Existing attempts to contextualise the composer's work generally focus on musical history - a subject that has received excellent treatment in the work of Sheila Fitzpatrick, among others, as well as Dorothea Redepenning, Wolfgang Mende, Levon Akopyan, and Stefan Schmidl ${ }^{1}$.

The importance of cultural history in a wider sense may be acknowledged, but this context is seldom thoroughly examined. Yet Shostakovich was, after all, not simply a musician and a composer: he was also a witness to some of Russian history's most traumatic events; he had a complicated personal life that expressed to the full the Russian late nineteenth- and early twentieth-century predilection for entangled emotional relationships; he saw (reluctant, but conscientious) service as a Deputy of the Supreme Soviet, a task

${ }^{1}$ See e.g.: Fitzpatrick S. The Lady Macbeth Affair // Fitzpatrick S. The Cultural Front: Power and Culture in Revolutionary Russia. Ithaca, 1992; Fairclough P. Shostakovich's Fourth Symphony: Context and Analysis. Ph.D Thesis, University of Manchester, 2002; Fitzpatrick S. Voldemort or Stalin? // London Review of Books. 2011. Vol.33, N 23. 1 December. P. 34-35; Akopyan L.: Dmitrii Shostakovich: opyt fenomenologii tvorchestva. St. Petersburg, 2004; Shostakovich i sovetskaya vlast': istoriia vzaimootnoshenii // D. D. Shostakovich: pro i contra. St. Petersburg, 2016. P.7-51; Schostakowitsch-Aspekte: Analysen und Studien / Hrsg. von D. Redepenning, K. Meyer. Berlin, 2014; Schmidl S. Oper in der "Traumfabrik Kommunismus": Zum Musiktheater im sozialistischen Ost- und Südeuropa der Stalinära // Österreichische Muzikzeitschrift. 2012. Bd. 67, N 7. S. 31-39; Mende W. Musik und Kunst in der sowjetischen Revolutionskultur. Köln, 2009. This subject also received reasonably neutral treatment in some works of the Soviet period, e.g.: Danilevich L. Dmitry Shostakovich: zhizn' i tvorchestvo. Moscow, 1980. 
that brought him an enormous and demanding postbag; and like many Russians, he was something of an artistic polymath, taking a considerable interest in ballet, painting, drama, literature, and many other areas of culture ${ }^{2}$. To find an analogy among artistic figures living in the West, one would probably have to go back to the nineteenth century, and then it would likely be a writer such as George Eliot or Charles Dickens, rather than a painter or composer ${ }^{3}$.

A second issue is the domination of work on Shostakovich by interpretive questions that don't fit the period being addressed. Particularly in the Anglophone world, there is a tendency to place at the centre of discussion the extent to which Shostakovich inwardly conformed to, or assimilated, the dictates of Soviet culture to which he outwardly assent$\mathrm{ed}^{4}$. With a historical subject who lived on into the late Soviet period and was therefore able to comment retrospectively on his own earlier behaviour, there is a serious danger of back-projecting later attitudes on to earlier eras. In line with this, interpretation of the early Shostakovich has been strongly influenced by memory of the 1960s and 1970s (when many Russian intellectuals saw principled opposition to the regime as central to the claim to be a poryadochnyi chelovek $)^{5}$.

There has been a widespread tendency, in retrospective interpretations of Shostakovich's life and musical career, to see him as caught between the warring forces of expediency and of personal morality. An account by his son Maxim captures this idea in the form of an anecdotal ekphrasis: "High up, over his bed, he had a little reproduction of Titian's painting 'Render Unto Caesar" "6. He used often to say to me: "Look how radiant Christ's face is. And below him is that dark nasty Pharisee showing him the coin and saying, "Why on earth do you pay tribute?' And Christ answers: 'Render to Caesar the things that are

2 The earlier part of Shostakovich's life is well chronicled in: Dmitry Shostakovich v pis'makh i dokumentakh/ ed. by I. Bobykina. Moscow, 2000 (henceforth DSPD). On the later period the edition by Oksana Dvornichenko contains some fascinating primary material related to the composer's work as a deputy, though unfortunately it is presented without scholarly annotations or even proper source notes. Moskva, Kreml'. Shostakovichu / ed. by O. Dvornichenko, Moscow, 2011.

${ }^{3}$ Perhaps André Malraux is the nearest analogy, though at a very different level of talent.

4 A recent example of this approach is Wendy Lesser's work (Lesser W. Music for Silenced Voices: Shostakovich and His Fifteen Quartets. New Haven, 2011) and, in the literary world, Julian Barnes's novel based on the life of Shostakovich (Barnes J. The Noise of Time. London, 2011).

${ }^{5}$ On this period, see e.g.: Alekseeva L. The Thaw Generation: Coming of Age in the Post-Stalin Era / Transl. by P. Goldberg. Boston, 1990; Zubok V. Zhivago's Children: The Last Russian Intelligentsia. Cambridge (MA), 2009. Cf. the comments of another leading oppositionist intellectual of the late Soviet period, Boris Gasparov: "Whatever the validity of Shostakovich's public and private utterances, no one claims, to my knowledge, to have heard from Shostakovich the shrill words of a public denunciation, similar to those that were addressed to him by so many critics, on so many occasions. He might occasionally sign a collective denunciation, joining a crowd of his colleagues (or rather, did not protest when his name appeared in print, alongside many others, sometimes without him having been even asked); but he never engaged in ideological witchhunting on his own initiative - a popular and profitable sport that proliferated in Stalin's time, and is not altogether unfamiliar to modern Western criticism. Whatever officious insipidities or subversive buffonades came or did not come from Shostakovich's mouth, denunciatory discourses aimed at unmasking the hidden ideological villainy were not among them. When, after a period in which he had been pushed to the brink of extinction, he rose once again in official favor - as happened more than once during his career he never used his regained stature to get even with those who had been demanding his head" (Gasparov B. A Testimony: Shostakovich's Fourth Symphony and the End of Romantic Narrative // Five Operas and a Symphony. New Haven, 2005. P. 165).

6 This painting, held in the Dresden Gemäldegalerie, goes under various titles. In Italian, it is known as Cristo della moneta (Christ of the Money), in English usually as The Tribute Money. The Russian title, however, is The Denarius of Caesar, from the Gospels story represented in Matthew 22:15-22; Mark 12:1317; Luke 20:20-26. 
Caesar's: and to God the things that are God's'"' My father used to say that Christ was purity and truth, and the Pharisee was everything false and disgusting" ${ }^{8}$.

Given that Maxim was born only in 1938, this memory must come from the last decades of Shostakovich's life. One can compare Solomon Volkov's record, in Testimony, of Shostakovich's tortured internal conflicts with the Moloch of the Soviet state ${ }^{9}$. Whether or not the text scrupulously records Shostakovich's actual conversations with Volkov (which I, like many, am inclined to doubt, though it may contain some authentic material), Testimony certainly purports to be a true and plausible record of Shostakovich's attitudes; and it does capture a view of the composer that is seen as at least partly authentic by those who knew him in his later years ${ }^{10}$.

Recent work on the early Soviet personality (for example, Thomas Lahusen and Jochen Hellbeck's studies of diaries and other forms of life-writing and self-representation) has suggested different models, where conscious non-conformity and conformity were not at issue $^{11}$. Instead, people were caught in a constant examination of their own worthiness, the tropes of which were strongly imprinted by suppressed Christian tradition. In this context, Shostakovich's apparent capitulation in 1936 might take on new resonance.

Another form of interpretation, likely more productive in the case of Shostakovich before 1930, emphasises the performative character of identity, where issues such as the genre in which someone was writing and the anticipated audience were crucial ${ }^{12}$. This well suits Shostakovich in the 1920s, given the ludic and wilful character of the work that he was doing, and of the fluctuation in his statements of position. The kinds of things that Shostakovich wrote to his mother in letters, such as: "By the way, I will have to pass elementary courses in political education and social science. Misha, Leva, Shebalin, Nikolsky, Starodumsky, and I are going to study for these exams together. We'll get through them somehow or other", suggest an attitude to political force majeure that was at once resigned and dismissive. Yet they were also situation-dependent, products of the collusive and informal character of a private correspondence ${ }^{13}$. God's'.

7 The Russian versions of all three Gospels phrase this slightly differently: “... and unto God what is

8 Shostakovich M. O zhizni i muzyke. Chast' 1. (2008) // Russkoe muzykal'noe obshchestvo. URL: http://www.irms.ru/shost04.html (accessed 01.06.2018).

9 Volkov S. comp. Svidetel'stvo. Vospominaniya Dmitriya Shostakovicha. (1979). Chast' 1. URL: $<$ modernproblems.org.ru/memo/148-shostakovich1.html (accessed 01.06.2018).

${ }^{10}$ On the dubiety in a textological sense of Svidetel'stvo, see: Fay L. Shostakovich Versus Volkov: Whose "Testimony"? // Russian Review. 1980. Vol.39. P. 484-493; Shostakovich: A Life. New York, 2005. Meanwhile, as is well known, Maxim Shostakovich has partly endorsed Volkov's portrait of his father, and the underlying assumptions about Shostakovich's attitudes (encoded opposition to Soviet power) have been restated by many of the informants cited in Elizabeth Wilson's interview-based work on the composer: Wilson E. Shostakovich: A Life Remembered. $2^{\text {nd }}$ ed.; London, 2006. Another insider who has supported Volkov's account is Vladimir Ashkenazy: see Ashkenazi V. Predislovie // Svidetel'stvo: Vospominaniia Dmitriia Shostakovicha. Chast' 1 / comp by. S. Volkov. URL: <modernproblems.org.ru/memo/148-shostakovich1.html> (accessed 01.06.2018).

${ }^{11}$ Lahusen T. How Life Writes the Book: Real Socialism and Socialist Realism in Stalin's Russia. Ithaca (NY), 1997); Kozlova N. Sovetskie lyudi: stseny iz istorii. Moscow, 2005; Hellbeck J. Revolution on My Mind: Writing a Diary under Stalin. Cambridge (MA), 2006.

12 This approach has more often been applied to recent discourse - see e.g. Utekhin I. Ustnye rasskazy o blokadnom opyte: svidetel'stva raznykh pokolenii // Antropologicheskii forum. 2006. N 5. P.325-344 but its insights would be applicable to first-person recollections in earlier periods as well.

13 Shostakovich: Letters to His Mother, 1923-1927. Selected by Dmitrii Frederiks and Rosa Sadykhova. Introduced, and with Commentary, by Rosa Sadykhova. Translated by Rolanda Norton // Fay L. Shostakovich and His World. Princeton, 2004. P. 10. 
In the end, such a letter tells us little more than that Shostakovich liked to posture and tease $^{14}$. Besides, a distaste for the dogmatic tenets of Communism did not necessarily go with lack of sympathy for the Soviet project in a broader sense. Another document from the 1920s, the questionnaire on his creative life that Shostakovich completed at the request of the musicologist Roman Il'ich Gruber, suggests that at this point, Shostakovich's artistic tastes were in some respects typical of the era. For example, of poetry, Shostakovich observed, "I don't have the slightest understanding of poetry, and I don't rate it either; two poets that I do like, relatively speaking, are Derzhavin and Mayakovsky"15.

The coupling seems on the face of it bizarre, and is hardly to be explained by political expediency. Certainly, Mayakovsky was ranked as an outstanding Soviet writer, though one whose status with the proletarian arts wing that Shostakovich himself was later to flirt with was becoming increasingly vexed. But yoking him to Derzhavin immediately abolished any advantage, in ideological terms, that the mention of Mayakovsky could have ensured. From the point of view of early Soviet aesthetics, Derzhavin was a conservative, indeed reactionary, writer from a period where feudal relations still held sway. Had Shostakovich mentioned, say, Aleksandr Radishchev, a notorious radical and thorn in the side of Catherine II, everything would have been clear. As it is, the two figures pull in different political directions. One possible conclusion is that Shostakovich was, at some level, actually saying what he meant; another, that he was simply intending to be outrageous.

Artistically speaking, too, the alliance seems surprising. Derzhavin was the towering figure of late eighteenth-century literature, when genres such as the court ode were still dominant, and when confessional autobiography had yet to emerge as a form of importance. Mayakovsky was a supreme exponent of late Romantic self-declaration. But there is an inward logic, and not just because both writers produced work that reflected the Realpolitik of their day. The point is that neither poet is primarily renowned for lyrical gifts: their work, often combative and challenging in stance and characterised by the jarring use of consonance, is a world away from the work of Pushkin, a writer who evidently left Shostakovich cold. If Pushkin was, as the Cubo-Futurists put it in 1912, to be "tossed from the steamship of modernity" Mayakovsky and Derzhavin were both possible passengers on that ship - even if one, so to speak, rode in steerage, and the other in first class.

This is not the only indication of an affinity of however approximate a kind, between Shostakovich and Mayakovsky. Shostakovich, of course, provided the incidental music for Meyerhold's production of Mayakovsky's The Bedbug in 1929. The alliance with Mayakovsky, loose as it may have been, suggests Shostakovich's general affinities with a "left arts" coalition at this point. This, it should be emphasised, had little to do with "Marxism-Leninism" of an official kind. The very term "Marxism-Leninism" is of dubious relevance at this period: from the late 1930s, the term was in regular use, but in the 1920s, a decade riven by disputes between a whole series of different artistic schools all campaigning for hegemony, the term did not yet have the authority it was later to acquire. As Mikhail Gessen put it in 1931, the problem in the first 15 years of Soviet power was to find out what was wanted at all ("What is now Marxist will become non-Marxist next

14 A point made, for instance, in: Taruskin R. Was Shostakovich a Martyr? Or Is That Just Fiction? // New York Times. August 26, 2016. URL: https://www.nytimes.com/2016/08/28/arts/music/julian-barnesthe-noise-of-time-shostakovich.html (accessed 01.06.2018).

${ }_{15}$ Anketa po psikhologii tvorcheskogo protsessa (No. 2 - 10 September 1927. Detskoe Selo) // DSPD. P. 473. Here and below, translations from Russian sources, where not otherwise credited, are my own. 
year") ${ }^{16}$. The time when writers and artists worried about how to comply with or evade the dictates of an aesthetic on which the Party leadership had conferred hegemony, Socialist Realism, still lay in the future.

The key force in aesthetic disputation in the 1920s was a rhetoric invoking "class war" (klassovaya bor'ba), and expressing a radical populism. For example, Mayakovsky's polemical piece, "Who LEF is Biting" (V kogo vgryzaetsya LEF), which appeared in the Left Front of Arts journal in 1923, sets out a programme that included artistic innovation ("we will campaign against the transfer of the methods used by the dead into today's art" [bold type original]), political engagement (among the antagonists named are "those who preach art that is above class and humanity"), and also those who invoke "the will of the people" in order to honour "traditions we have inherited from our great-grandmothers". Mayakovsky also attacked the "foundational slogan of comprehensibility to all" 17 .

This view of a radical, engaged art that would challenge, rather than confirm, the tastes of the anticipated audience is clearly of the first importance to the composition of the works that Shostakovich wrote in the late 1920s, such as Conditionally Murdered [Uslovno ubityi] ${ }^{18}$. Central at this period was also Shostakovich's commitment to a leftmodernist-oriented artistic dynamism. "'Painting doesn't get across to me, and I think it's a pointless activity. I've made every effort to get to know the museum collections in Leningrad and Moscow, but it hasn't worked: it's the static character of it all that puts me off', he observed to Gruber, insisting, 'You'll never find a moment of "standing still" in nature'". From this general condemnation, however, he excepted caricatures, and also the drawings of Yury Annenkov (vivid, angular sketches that give a strong sense of motion, as in the famous street scenes illustrating Blok's revolutionary poem The Twelve) ${ }^{19}$.

\footnotetext{
${ }^{16}$ Music and Soviet Power / eds M. Frolova-Walker, J. Walker. Woodbridge, 2012. P. 315.

17 Mayakovsky V. V kogo vgryzaetsya LEF // LEF. 1923. N 1. Cited here from Mayakovsky V. Polnoe sobranie sochinenii. Vol. 1. Moscow, 1959. P. 45-46.

18 It is dubious how much Marxism-Leninism in a strict sense can be considered to be of relevance to Soviet art at any period. In the Stalin era, Soviet patriotism and loyalty to the dictates of the Party and the leader as its living embodiment (partiinost') were considerably more important than a command of Marxist theory, as the rout of the so-called "vulgar sociology" movement - the analysis of literary and cultural forms on the basis of classical Marxism - clearly indicated. In the post-Stalin era, it was academic institutions, such as the Institute of Ethnography of the Academy of Sciences, where Marxist-Leninist principles were of greatest relevance (see e.g. the Soviet contributions to Geller E. (ed.).: Soviet and Western Anthropology. London, 1980). On the other hand, a command of the "classics of Marxism-Leninism' was not considered essential for creative artists. Expressing amused consternation at plans to teach actors the principles of economics, one Leningrad Party official remarked in 1971, "You have to know your limits!" Sometimes it was difficult to get actors to say two words during political discussions, "and ballerinas and opera singers have their little ways as well". Seminars on Marxist-Leninist aesthetics were replaced, in many theatres, by collective visits to cultural events, followed by discussion (Stenogramma soveshchaniia propagandistov i zamestitelei sekretarei partiinykh organizatsii uchrezhdenii literatury i iskusstva g. Leningrada po teme: "O perspektivakh sovershenstvovaniia partiinogo obrazovaniia tvorcheskoi intelligentsii", 18 November 1971 // Tsentral'nyi gosudarstvennyi arkhiv istoriko-politicheskikh dokumentov, St. Petersburg (TsGAIPDSPb). F. 24. Op. 145. D. 12. L. 13, 1. 15, 1. 8). In the 1920s, the situation was of course different, but the records of the Leningrad film studio indicate that ideological education was primarily used for the purposes of filtration, i.e. the classification of staff into "us and them": see e.g.: TsGAIPD. F. 1369. Op. 1. D. 84. L. 11: "The work of the Party has been conducted as a vehement struggle with the opposition; it has been essential to use statistical data to highlight the slanderous [sic., klevetnicheskie] squeals of the opposition; take, for instance, the 5-year plan for the development of industry" (Party meeting of the collective of Sovkino, Leningrad, 3 November 1927).

19 Anketa po psikhologii... P. 474.
} 
The emphasis fully accords with the tropes of the time. For example, a 1928 brochure published to aid worker writers who wanted to publish in Soviet newspapers had emphasised the need for "mobility and flexibility" (podvizhnost' i gibkost'), as well as the capacity to "react quickly to the most important events in our country" (bystro otkliknut'sya na vazhneishie yavleniya $v$ zhizni nashei strany) and to "mobilise [the worker mass] for the struggle with evil and the support of good" (mobilizovat' [rabochuyu massu] na bor'bu s plokhim, na podderzhku khoroshego $)^{20}$. Here one has something in line with the Manichean world of Shostakovich's early work for the theatre, which is entirely in the traditions of the agitka, or "agitational sketch".

If "comprehensibility to all" was to be rejected, this did not mean ignoring the needs of a mass audience. Alongside his lukewarm commendation of Mayakovsky and Derzhavin, and far more enthusiastic recognition of the values of writers such as Dostoevsky, Shostakovich also identified himself with the populist aesthetic of Leo Tolstoy: "As an artist, Tolstoy is not very congenial (as a theorist of art, what he says is in many respects convincing" ${ }^{21}$. What Shostakovich had in mind was no doubt the treatise What is Art? (1898). Here Tolstoy set out a model of art as emotional exchange - whereby artists' primary task is the transmission of feelings to others. What is Art also vehemently argued for the futility of elite art, and conversely, the superiority of popular (narodnoe) art to excessive sophistication (better a folksong than Beethoven quartets). The fact that folk music was accessible to the public was Tolstoy's primary consideration (though he certainly attacked the cult of Pushkin on the grounds that the common people would not understand it). Rather, Tolstoy held folk art intrinsically superior to elite art: simplicity was an aesthetic virtue in itself.

In sum, what we know about Shostakovich's artistic preferences in the 1920s confirms the 1924 comment from M. O. Shteinberg, one of his teachers at the Conservatoire, that the young Mitya had begun working in an "extreme leftist" manner ${ }^{22}$. But I would argue, this was less a question of openly articulated and theorised conviction than of the general Zeitgeist. Shostakovich himself, in 1927, represented his own artistic preferences in terms of a battle with the older generation - as personified by Sheinberg himself: "In 1922, I composed a Suite for Two Pianos. Professor M. O. Shteinberg reacted to it with some hostility and told me to correct it. I did not do this. Then he once more insisted that I should correct it. That time I did rework it according to his instructions. In that guise, it was performed at a student concert in LSC [Leningrad State Conservatoire]. After the concert, I destroyed the corrected score, and started to write down the first version again. M. O. [Shteinberg] was not at all pleased about this. It was one of my first attempts at 'rebellion' against the dictatorship of 'rules'"23. The Russian text of Shostakovich's comments contains an untranslatable play on the thrice-repeated pravit' (to "correct") and pravila (rules). Shostakovich's struggle with these is jokingly given a contemporary political resonance by the words "dictatorship" and "rebellion". Thus we can see that personal self-assertion and the revolutionary struggle could be rhetorically associated.

${ }^{20}$ Polotskaya N., Dokunin V. Redkollegiia stennoi gazety i kruzhok rabkorov. Moscow, 1928. P.7.

21 Anketa po psikhologii... P. 474.

22 Shostakovich v dnevnikakh M.O. Shteinberga / ed. by O.Dansker // Shostakovich. Mezhdu mgnoveniem i vechnost'yu: dokumenty, materialy, stat'i / ed. by L. G. Kovnatskaya. St. Petersburg, 2009. P. 99. (Entry of 29 January 1924).

${ }^{23}$ Anketa po psikhologii... P. 472. 
I would contend that this inchoate identification with "revolutionary struggle" was in many respects attributable to the specific and contradictory effects of experiencing the actual revolution at the precise age when Shostakovich did. He was, after all, only 9 when it began, and his maturity as an artist and high intelligence should not be confused with a detailed awareness of the meaning of the events that he witnessed, let alone their longterm consequences. In other words, to expect from him the kind of horrified reaction characteristic of, say, Anna Akhmatova (born in 1889, and an established artist when the Revolution took place) would be futile. At the same time, to assume that he was automatically uninterested in politics because of his tender age would be equally misplaced. As the psychologist Robert Coles has argued in an impressive study based on interviews with young children, those growing up in highly politicised societies very early acquire sensitivity to the events and discussions around them - even if they see these from a perspective that may not resemble the perspective of adults ${ }^{24}$. This generational factor to date pretty well ignored in discussion of the composer's biography - deserves detailed analysis. To do full justice to the question would require extensive specialised research, but at least a preliminary investigation seems warranted, and such will be attempted here.

\section{“Children of Revolution"}

For most commentators, Shostakovich's childhood experience (before he began studying at the Conservatoire) has been of peripheral interest at best ${ }^{25}$. What is more, this period of the composer's biography, like other episodes in his life history, has been occluded by tendentious efforts to legitimate an integrated and coherent version of his overall biography as either "pro" or "anti" Soviet by inclination. Sof'ya Khentova's many overlapping accounts of his life are entirely consistent with the ideologies of the period at which they were produced (the revival of the Lenin cult during the Khrushchev and Brezhnev years, which was particularly important in Leningrad, officially known as "the cradle of three revolutions"). Khentova's demonstration of Shostakovich's sympathy with the Bolshevik Revolution is primarily circumstantial: she talks at length about the revolutionary credentials of Shostakovich's parents, and of the district of Petersburg in which they lived ${ }^{26}$. She describes young Dima's direct participation in the key events leading up to "October" - in particular, the excited rush to the Finland Station to cheer on Lenin's return to Petrograd on the armoured train, the episode later memorialised in the statue that still stands today on what is still called "Lenin Square"27. Solomon Volkov's account is, equally characteristically for the governing mythology of his text (a product of the late Soviet cultural underground), a neat inversion of Khentova's Soviet canonisation: Shostakovich greeted the Revolution with a mixture of bemusement and indifference. He remembered standing outside the Finland Station, yes, but had no idea what all the fuss was about. Had he real-

${ }^{24}$ Coles R. The Political Life of Children. Boston, 1986. Coles's examples include, for instance, Northern Ireland.

${ }^{25}$ For instance, MacDonald gives Shostakovich's childhood about 10 pages, under the title "Innocence" (MacDonald I. The New Shostakovich. London, 1990. Chapter 1; Laurel Fay, while not declaring her hand so obviously (the chapter has the title simply, "Childhood"), accords this period a similar number of pages (Fay L. Shostakovich: A Life... P. 7-16).

26 See e.g.: Khentova S. M. Shostakovich: zhizn' i tvorchestvo. In 2 vol. Leningrad, 1985-1986. Vol. 1. P. 84; Davydenkov L. Shostakovich: zhizn' i tvorchestvo. Moscow, 1980.

27 Ibid. 
ised at the time what an august personage was causing it, he would have been sure to pay closer attention (here Shostakovich, or Volkov's, sarcasm is palpable) ${ }^{28}$.

Both Khentova and Volkov's versions have since been assailed from the point of view of strict fact. Boris Lossky's meticulous and detailed account of 1917 and 1918, "Our Family in the Savage Years" first published in 1993, pointed out that Lenin had arrived at the Finland Station at around $11 \mathrm{pm}$, making it exceptionally unlikely that a nicely-broughtup ten-year-old would have been out and about the city streets at the time ${ }^{29}$. Indeed, the version given by Khentova makes it sound as though a crowd of schoolchildren had rushed over together. This makes topographical sense - the school that Shostakovich attended, the Shidlovskaya College at no. 7 ulitsa Shpalernaya, was about 20 minutes' walk away from the Finland Station, across the Liteinyi Bridge - but would be plausible in temporal terms only if the event that they witnessed had happened during school hours ${ }^{30}$. Lossky also argues that Shostakovich himself probably did not witness the death of a boy in July 1918 that inspired the composition of his early piano piece, "Funeral March for the Victims of Revolution": instead, it was likely his sister Musya, who had this experience, so that the incident which later came to ornament the composer's account of revolutionary struggle was in fact the product of hearsay ${ }^{31}$. Recent Western accounts, such as Laurel Fay's biography of Shostakovich, published in 2000, have taken a similar standpoint to Lossky's. Fay concedes that Shostakovich's family is likely to have been generally sympathetic to political change, but is disinclined to accept any concrete association of Shostakovich with the revolutionary struggle. At the same time, she uses Lossky's information about Lenin's arrival at the Finland Station in order to call into question Volkov's account of that episode as well ${ }^{32}$.

These scruples are understandable. Neither Khentova nor Volkov's accounts can be termed scholarly in terms either of approach or method. Unannotated, partial, and sometimes careless in their use of evidence, they at best coincide with the truth at some points, rather than attempting to engage with this ${ }^{33}$. But their critics such as Fay and Taruskin, for all their incomparably greater intellectual authority, also have certain blind spots. To begin with, the process by which the Revolution was mythologised is also a historical fact, and one of the greatest importance in shaping Soviet perceptions of the self. As Frederick Corney's masterful study, Telling October, has shown, the early 1920s was a period when systematic work was done on rescripting the eyewitness testimony of those who had actually participated in the Bolshevik Revolution, and creating canonical versions of the sequence of events and the details of what happened. By 1927 (the tenth anniversary of "October") the process of rescripting was to all intents and purposes complete, and from now on

${ }^{28}$ Svidetel'stvo. Vospominaniia,..

29 Lossky B. Nasha sem'ya v poru likholet'ia // Minuvshee. 1992. N 11. P. 169.

30 Some Petrograd schools operated a "double shift" system after the Revolution (with the second shift finishing around $10 \mathrm{pm}$ in the evening), but it is not clear whether the Shidlovskaia School was one of them.

31 Lossky B. Nasha sem'ya... P. 169.

${ }^{32}$ Fay L. Shostakovich: A Life...

${ }^{33}$ For instance, I would not at all rule out that both versions of the Finland Station are based on what in Russian are termed baiki, or "taradiddles", told by Shostakovich himself. These self-mythologising anecdotes are a widespread feature of what the anthropologist Nancy Ries has called "Russian talk": see Ries N. Russian Talk: Culture and Conversation during Perestroika. Ithaca (NY), 1997. Lidiia Chukovskaia's records of her conversations with Anna Akhmatova include many examples from the poet's repertoire: Chukovskaia L. Zapiski ob Anne Akhmatovoi. In 2 vol. St. Petersburg, 1996. 
"revolutionary memory" was essentially a constant repetition of the established master-plot ${ }^{34}$.

Corney's account perhaps underestimates the potential for modulation in later periods of Soviet power, but the central argument about the governing mythology of "October" is cogent. Put bluntly, if people did not have the "right" memories of "October", they were near-certain to acquire them. It is perfectly possible that Shostakovich genuinely thought, by the 1960s, if not earlier, that he had really witnessed Lenin's arrival in Petrograd. (And, assuming there was any factual basis for this idea, it may have come from understandable confusion with some other large political meeting on Vyborg Side, the district where the Finland Station is situated, which really was a hotbed of revolutionary activity).

With an event so crucial, yet also so amorphous, as the Revolution, memories were in any case likely to become confused and transmuted. Already in 1924, a boy who had also witnessed the events in Petrograd at a tender age wrote in a school essay:

"I can only cite a few impressions of 1917 that have been clearly preserved. Most of them have been effaced by new impressions, or have been forgotten to an extent that I cannot recollect them without distorting them to fit the patterns of today. My impressions of back then are being forgotten to a greater and greater extent, no doubt because they are less and less in tune with my character today. It would seem that my understanding of things now, and my understanding seven years ago, are completely different" ${ }^{35}$.

Many of the commentators on Shostakovich's biography seem to ignore the process of what the literary theorist Mikhail Bakhtin called "narrative double-voicing". Remembrance is always a dialogical process of interaction between "back then" and "now", and the effaced and forgotten traces of the past may seem more "authentic", in psychological terms, to someone who is in the process of remembering an event, than does anything set out in the documentary records, precisely because the latter are so far removed from the present $^{36}$.

In this context, what is significant to Shostakovich's creative processes in the 1920s is not what he "actually" (in inverted commas) did and saw in 1917 and 1918, but what he imagined having done and seen. In his Second Symphony, composed for the tenth anniversary of "October", the historical upheavals of revolution are evoked in a spirit of heroic jubilation. This was, of course, a contribution to precisely the canon-making process of which Corney writes. But at the same time, this does not necessarily make the work "insincere" or "inauthentic" (neiskrennee). Unless a diary or similar extempore record of Shostakovich's reflective processes in his early years comes to light, our judgement on these has to remain speculative. (And even then, we might have cause to doubt the ultimate "truth value" of a diary, given that in public ages, such documents are written with an eye on their public significance $)^{37}$. Whichever way, there is quite a lot of evidence that

${ }^{34}$ Corney F. Telling October. Memory and the Making of the Bolshevik Revolution. Ithaca (NY), 2004.

35 Anonymous male pupil in class six of the real'noe uchilishche (Realschule) at Zemun, Yugoslavia // Deti russkoi emigratsii: kniga, kotoruyu mechtali i ne smogli izdat' izgnanniki / ed. by L. I. Petrusheva. Moscow, 1997 [henceforth DRE]. P.487. On the project from which this testimony stemmed, see further below.

36 We might remember in this context also Yosef Yerushalmi's contention (Yerushalmi Y. Zakhor: Jewish History and Jewish Memory. Seattle, 1982) that it is history that is peculiar and requires special historical arguments to explain, not legend or mythology.

37 This point is made, for instance, in: Hellbeck J. Revolution on My Mind. 
this spirit of heroic jubilation was the one in which large numbers of the "children of the Revolution" - those who, like Shostakovich, witnessed the Revolution when they were still very young - experienced the Revolution and its aftermath.

As Shostakovich's near-contemporary, the poet Ol'ga Berggol'ts (born in 1910) recalled, 30,000 schoolchildren took part in the celebrations for the First of May 1919 held in Petrograd, carrying flags decorated with flowers and garlands to the main building of the People's Commissariat of Enlightenment on ulitsa Chernyshevskaya, and singing the Internationale so loudly that Lunacharsky, who was meant to address the procession, could not make himself heard above the din. And in May 1923, schoolchildren processed through Petrograd as part of a demonstration against Lord Curzon, shouting slogans ("We're Bored! With You, Lord!") and singing political songs, first and foremost, the Internationale, then the unofficial national anthem of the new state ${ }^{38}$.

Since Berggol'ts's recollections of these events come from a memoir published in the Soviet Union in 1972, one might be inclined to dismiss them, though it should be noted that Berggol'ts became, in the post-war years, a brave critic of Soviet power, whose nostalgia for the early days of communes and radical collectivism did not impede her sharp analytical understanding of the history that she had lived through. (Like, one might say, Shostakovich at the same period; and Berggol'ts, too, was regarded by convinced oppositionists, including Anna Akhmatova, as a poryadochnyi chelovek with whom it was possible to associate.) But evidence of children's enthusiastic response to the events of 1917 comes not only from Soviet sources. Extremely interesting in this regard is the collection of essays from which I took the quotation about the peculiarities of memory cited above, the context and contents of which deserve discussion in a little more detail.

In 1924, the Zemgor Association, a welfare organisation founded by participants in the zemstva, or local authorities, of pre-revolutionary days, and which sponsored and promoted a broadly-based programme of philanthropic activities across the Russian diaspora scattered over Western and South-Eastern Europe and Turkey in the aftermath of the Revolution and the Russian Civil War (1918-1921), organised a project aimed at collecting the memories of young people. Schoolchildren studying in a variety of schools run by Russian émigré communities were asked to write down what they could remember about their lives as a classroom exercise. This generated hundreds of mini-autobiographies detailing the experiences of individuals who had witnessed the events concerned at anything from three or four up to fifteen or sixteen years old. (Because of the interruptions to education that they had endured, some of these "schoolchildren" were already in their 20 s when they wrote up their accounts, but others were considerably younger.)

In 1925, a selection of the autobiographies was published by Zemgor, but most did not see the light of day at this point ${ }^{39}$. In 2001, a further selection of material appeared, presenting autobiographies from children living in Bulgaria, Czechoslovakia, Yugoslavia, and Turkey. Even this is not a complete record, and the texts have evidently been heavily edited in order to adapt them to standard grammar, punctuation, and spelling ${ }^{40}$. But the

38 Berggol'ts O. Dnevnye zvezdy. Leningrad, 1971. P. 152-153.

39 Deti emigratsii. Prague, 1925. The edition was reprinted in 2001, and is also available online at URL: $<$ rus-sky.com/history/library/vospominaniya > (accessed 01.06.2018)

40 I base this statement on extensive work with children's testimony for the collection that I edited with Vitaly Bezrogov: Bezrogov V., Kelli K. Gorodok v tabakerke: detstvo v Rossii ot Nikolaya Vtorogo do Borisa Yel'tsina. Vzroslye o detyakh i deti o sebe. In 2 vols. Moscow; Tver', 2008. 
number of autobiographies produced is quite significant, and the patterns that emerge allow a reasonable degree of generalisation.

As with any sources, children's autobiographies, and especially those produced "to order", for a classroom exercises, have their own pitfalls. Marina Tsvetaeva's daughter, Ariadna Efron, who took part in the exercise when studying at the Gymnasium in Moravská Třebova, Czechoslovakia, was later to allege that many of the children could remember very little of what had happened to them and had simply started to make up increasingly fantastic events, desperate to fill up the piece of paper ${ }^{41}$. But the comments of individuals of approximately the same age as Shostakovich who also witnessed the Revolution in Petrograd are all the same quite revealing ${ }^{42}$. It is notable, for instance, that despite the fact that the children concerned came from the homes of well-off, well-educated parents, many of them remember that the first response inspired by the peculiar events of 1917 was euphoria. As the boy whom I earlier quoted put it:

"Suddenly you could hear shots and motor-cars with armed people began passing below our windows. They were shouting something and shooting. Below our windows on the [Palace] Square side stood a patrol of Cossacks, and they were shooting at the motor-cars. It struck me as a complete novelty, good fun, even. I didn't attempt to get to the essence of things, since I didn't understand what was happening anyway. The sense that Tsarist rule was being overthrown didn't occur to me, because I had no idea that you could overthrow it. Instead, I reacted in the same way as I did to any of the festivals and parades that you could often see out of our windows, only this was even more interesting than usual, because there was shooting too" ${ }^{43}$.

This sense of having experienced events that were at once bizarre and exciting is typical of accounts from boys who were roughly Shostakovich's age, that is, around ten, when the Revolution took place, and who came from a similar social background (comfortably off materially, but not from the actual aristocracy) ${ }^{44}$. In the circumstances, a position of indifference, if one was old enough to be aware of one's surroundings at all, was unlikely. "Politics was everywhere", recalled Igor' Alekseev, who was 14 when the February Revolution took place, about the months leading up to the disorder ${ }^{45}$.

This testimony from émigré children had its own ideological context (the accounts are uniformly anti-Bolshevik). But at the same time, in some respects, the children's memories confirm the testimony of, for example, Berggol'ts. In other words, the claim that

${ }^{41}$ Efron A. O Marine Tsvetaevoi: Vospominaniia docheri. Moscow, 1989. P.233.

42 This is true also of the autobiographies that schoolchildren wrote before 1917, as a compulsory exercise for the graduating classes of educational establishments from primary level up. On those produced at parish schools and other establishments run by the Educational Council of the Holy Synod, see: Kelly C. Kak sdelany vospominaniia: deti i lichnoe proshloe v Rossii nachala XX veka // Istoricheskaia pamiat'i obshchestvo v Rossiiskoi imperii i Sovetskom Soyuze (konets XIX - nachalo XX veka). Mezhdunardonyi kollokvium. Nauchnye doklady. St. Petersburg, 2007.

43 DRE. P. 487.

44 An account by an aristocratic girl, N.Gagarina, is very different, recalling the burning of the Nikolaevsky (now Moscow) Station, and hiding inside the house with darkened windows and bolted doors to avoid attracting attention, see: DRE. P.306-307. Even she, however, remarks that no-one took the Bolsheviks seriously at first: "No-one thought back then that such a tiny gaggle of people could get their hands on political power. Everyone treated the Revolution insouciantly and didn't think about the consequences". The sense of dread pervades another account by a girl (anonymous, born c. 1907): DRE. P. 355 .

45 Igor' Alekseev, born c. 1902: DRE. P. 300. 
at least some children had revolutionary aspirations is not a Soviet fabrication. Yet one needs to bear in mind that children of around ten were, as Leninist terminology puts it, not "conscious", in the sense of politically literate. In 1905-1906, large numbers of school pupils took part in the uprisings that raged all over the Russian Empire. Surviving documents indicate that the juvenile participants had their own agenda (involving the right to smoke at school as well as democratic representation for pupils on school councils and the cession of control over discipline to pupils themselves) ${ }^{46}$. Equally, the child participants in the events of 1917 did not always respond to what they saw as adults might have done. Igor' Alekseev remembered that he had sat with Mara, the object of his calf love, while her mother wept hopelessly all night in his mother's bedroom because Mara's father had been arrested. Igor' and Mara had their minds on other things: "turned back into children again, we completely forgot our 'flirting' (as the fashionable term among young people then was), and we indulged in childish dreams of saving the Tsar" 47 .

Alekseev's later life was testimony to the accelerated development that many experienced during the revolutionary years. By May 1917, he was managing his parents' estate in Kherson province since his father was too ill to cope; in the first half of 1919 (when he was still only 16 or 17) came "dressing up in disguise, going into hiding, terror, arrests, home-distilled vodka and cocaine; some people were murdered and tortured, or imprisoned, friends and relations were arrested" 48 . This second reminiscence points to another factor in the impressions of those who witnessed the days of revolution as children: the horror inspired by glimpses of violence. It might have been good clean fun to hear the whizz of flying bullets, but when they hit human flesh, reactions were different. A young man who was at cadet school in Petrograd when the Revolution started recalled a horrible sight that he and schoolmates had seen over a fence on the embankment: "There on the ice, where a few days earlier they'd been playing music and people had been happily tobogganing down the ice hills, the bestial shooting of some people (later we found out, it was [Tsarist] policemen) was taking place." The boys were observed and had to take refuge from bullets themselves ${ }^{49}$. As well as witnessing atrocities first hand, children might hear about these from others: one boy recalled how his father had arrived from Petrograd in Odessa, where the family had taken refuge, to report that in the city, "pools of blood were lying everywhere", as well as corpses, and that robberies were rife, as were burnt-out houses as the result of $\operatorname{arson}^{50}$. And of course, children also experienced the terrible material privation of the first post-revolutionary years. As Nikolai Rosenkranz, about 17 when the Revolution took place, remembered, "You could see these depressing scenes on the streets: dead horses, sometimes people collapsed in a faint from hunger. We often didn't have even a crust at home, even the mice vanished" 51 .

There is, then, abundant objective correlation of the mixture of euphoria and dread as characteristic constituents of the memories of youngsters around Shostakovich's age when they looked back to the days when revolution raged. Participation in meetings on the one

46 See Kelly C. "The Lads Indulged Themselves: They Used to Smoke": Tobacco and Children's Culture in Twentieth-Century Russia // Tobacco in Russian History and Culture: From the Seventeenth Century to the Present / eds by Matthew P. Romaniello, Tricia Starks. New York, 2009.

47 DRE. P. 300.

48 Ibid. P. 301.

49 Anonymous male, class 6, Realschule, Zemun, age not given (born c. 1902?): DRE. P. 491-492.

50 Ibid. P. 484.

${ }^{51}$ Ibid. P. 298. 
hand, and the witnessing of brutal killings on the other, are commonplaces of the Zemgor essays. By extension, the assumption that the presence of these motifs in Shostakovich's recollections is purely explained by an expedient desire to lay claim to the "right" sort of memories is certainly unwarranted. Even Boris Lossky (whose attitude to the revolutionary period is made clear by his allusion to it in the title of his memoirs as "years of savagery") recalls hearing Shostakovich play his "Funeral March for the Victims of Revolution", and recollects that the staff of the Shidlovskaya College "surely included quite a few socialists", and that there were plenty of boys who were eager to sing revolutionary songs and who were thoroughly excited by the atmosphere of upheaval ${ }^{52}$ - a mood which another early piece by Shostakovich, "A Hymn to Freedom", also evoked.

Yet one should emphasise again that this was not "consciousness" in the Bolshevik sense. The supporters of the new regime sought not so much to encourage children and young people's enthusiasm, as to channel this in useful ways. The statements by Lenin and Trotsky that saw youth as the nation's future also implied coercion: the young were to be turned into fiery activists who could lead their elders in appropriate ways. The "elemental" social participation that came from young people when not directed was the subject of suspicion, rather than admiration. An amusing demonstration of this occurred in October 1924, when a group of Pioneers decided that they wanted to engage in an act of revolutionary refashioning, discarding their "religious" first names and adopting politicised new ones, such as RKP (Workers' and Peasants' Party) and Kim (Communist Youth International). The response to this from Pioneer and Komsomol leaders was anything but rapturous: the children, instead of being congratulated, were expelled from the Pioneer organisation ${ }^{53}$. Discipline of a militarised kind was a more characteristic, and enduring, part of Bolshevik culture than colourful protest. The whole of Soviet youth, like the population more generally, was supposed to engage in a mission of vospitanie (moral education) and of rabota nad soboi (work on the self): protest was regarded less positively than purposive discussion (for example, participation in reading groups that studied Bukharin's The ABC of Communism, carefully repeating and assimilating the ideas set out there). Efforts to integrate oneself into the rational collective were essential, and those who displayed the lack of capacity for due "self-criticism" would have the weapon of criticism turned on them from the outside ${ }^{54}$.

The revolutionary aspirations of the "first Soviet generation" were vulnerable from other points of view too. It was customary in the revolutionary arts to represent political upheaval as a carnival: Eisenstein's The Battleship Potyomkin ends with the rebel ships greeting each other joyously as they sail out into the open sea. In the case of children, the carnival could be literalised, as youngsters poured from their classrooms into the street. Yet carnival celebration, as Mikhail Bakhtin was to argue in his famous study of Rabelais, on which he began work in 1936, during the aftermath of revolution, was ambiguous and unstable. It left unassailed the tenets of the system that it inverted. The interior sense that protest was shortlived and extraordinary, that it would be followed by a return to "normal-

${ }^{52}$ Lossky B. Nasha sem'ya ... P. 169.

53 Zapis' razgovorov detei v detskoi chital'ne Moskvy v 1924 // Rossiiskaia Akademiia obrazovaniia. Nauchnyi arkhiv (RAO NA). F.5. Op.1. D.59. L.280. My thanks to Steve A.Smith for passing on this reference.

54 These processes are discussed in detail in: Kharkhordin $O$. The Collective and the Individual in Soviet Culture. Berkeley (CA), 1999. 
ity", could help to explain the rupture between Shostakovich in the years before 1936 and thereafter.

\section{"Freedom" and "Discipline": The Contradictions of an Early Twentieth-Century Education}

Another aspect of Shostakovich's early experience that was critical to his later development was his exposure to contradictory forms of socialisation. His early schooling, and indeed upbringing, was shaped by the ideals of what is known in Russian as "free education" (svobodnoe vospitanie) (this translates into German, as "freie Erziehung", more easily than it does into English). In the 1900s and 1910s, large numbers of well-educated, middle-class Russian parents were inspired by the theories of Froebel and Montessori. Modern methods of upbringing and education were even satirised in a cartoon published in the St. Petersburg satirical magazine The New Satiricon, a clear indication of their popularity ${ }^{55}$. Shostakovich's relationship with his parents, as indicated by his highly informal and affectionate letters to his mother, not to speak of her extraordinary concern to support a son whose exceptional talents she constantly asserted, was very much in the spirit of "free education"56. In turn, her encouragement of his early musical efforts was in the spirit of an era that encouraged children's creativity, with Aleksei Kruchenykh's Children's Own Stories and Drawings (1914) an example of how leading modernists of the day took a direct interest in juvenile artistic production as an inspiration for their own ${ }^{57}$. (Just so, the painter Mikhail Larionov was an enthusiast for children's compositions, as shown in his collection of drawings by the young as well as in the style of his own compositions).

Shostakovich's parents took care to send him to a school that suited these patterns of development. In biographies of Shostakovich, the Shidlovskaya College is usually presented as an institution that appealed because of its programme of technical subjects, and it is claimed that Shostakovich's parents sent him there because they hoped he would follow in his father's footsteps and become an engineer. This may well have been true, but the Shidlovskaya College was in fact an educational establishment whose most characteristic features were of rather a different kind.

In sending their daughter Mariya, and later her younger sister Zoya, to the Mariya Nikolaevna Stoyunina Classical High School, Dmitry and Sof'ya Shostakovich were making clear their ambitions to be progressive parents. Founded in 1880 by a leading member of the Petersburg intelligentsia (married to the prominent teacher Vladimir Yakovlevich Stoyunin, its initiator was also a friend of Dostoevsky), the school was renowned for its espousal of modern methods, including a heavy reliance on visual aids; formal marks were rejected in favour of continuous assessment, and an "individual approach" that sought to

${ }^{55}$ I have discussed all this in detail in: Kelly C. Children's World: Growing Up in Russia, 1890-1991. New Haven, 2007. Ch. 1.

56 See e.g. S. V. Shostakovich's letter to B.L. Yavorsky, 1 May 1925: "I'm very sad that with every step, dear Mitya is moving further away from me and my role in his life is becoming totally insignificant, and I'm even afraid that he finds me wearing at time, and I even put up with this, and without any real trouble, because I am so convinced of his intelligence and his talent. But when it comes to his health, I must make every effort to make sure he does not perish. Please accept what I say: the only person who is able to think about that side of things is his useless old mother. And so I am condemned to wage war on all Mitya's friends, on whom, as you can well imagine, the question of his health and life makes no impact at all" (DSPD. P. 15).

57 Kruchenykh A. Sobstvennye rasskazy i risunki detei. St. Petersburg, 1914. 
focus on pupils' own particular abilities. The school pioneered the teaching, in Russia, of physical education (under the famous teacher of the subject Petr Lesgaft), and in the 1890s, acquired a model primary school for poor children, and also its own kindergarten ${ }^{58}$.

The Shostakoviches were, evidently, keen to place their son also in a school that combined intellectual and progressive credentials, rather than sending him to an ordinary classical high school, which were sustaining increased criticism in the early twentieth century, as places that both overburdened pupils with dry academic work and operated a repressive regime ${ }^{59}$. Conceivably, they might have chosen the Tenishev College, on Mokhovaya ulitsa, founded in 1900, and the most prominent St. Petersburg school offering a liberal education of the English public school type. However, the fees charged by the Tenishev were exceptionally high - mnearly ten times as much as those exacted by the state-run Classical High Schools - which may have been a factor. Distance was certainly not the issue: the school's location made it about ten minutes' walk nearer than the establishment that they eventually chose ${ }^{60}$. Whichever way, their eventual selection was different - a much less well-known school, but one whose approach to educating the pupils in its care was equally experimental.

On 19 January 1910, Mariya Aleksandrovna Shidlovskaya petitioned the Minister of Trade and Industry for permission to open an "eight-class commercial college for boys, with the right to accept girls by special permission of Your Excellency" ${ }^{\text {61 }}$. After supplying a draft budget for equipment and a timetable of lessons for the different year groups, and after the obligatory check with the city governor's office that she had no record of political subversion, Shidlovskaya obtained the necessary permission in early May, and later that month, forwarded to the Ministry the statutes (Ustav) of the fledgling college, which stated that its purpose was to offer pupils "a general and commercial education". As well as a library, teaching aids, and laboratories for physics and chemistry, Shidlovskaya's school had a "museum of model goods"; alongside the classes that offered teaching to senior pupils, it also had a "preparatory" section for younger children ${ }^{62}$. In its first years, the school was extremely small: in 1912, the total number of children on the books was 32, clustered in the younger year groups (the two preparatory classes included nearly half the total numbers of pupils $)^{63}$. Given that it was common at the time for classes in state secondary

${ }^{58}$ Dvadtsatiletie Zhenskoi gimnazii M.N.Stoyuninoi 1881-1906 gg. No place or date given. [St. Petersburg, 1906]. Spravochnaya knizhka Zhenskoi gimnazii M. N. Stoyuninoi. St. Petersburg, 1908. For the general context, see: Maidanova S. Yu. Obrazovatel'nye sistemy chastnykh zhenskikh gimnazii Rossii vtoroi poloviny XIX - nachala XX v. // Vestnik of Tomsk State University. 2007. N 303. P.99-101.

59 During the 1905 "year of revolutions", there were widespread protests on these fronts by pupils, including groups in St. Petersburg. Leaflets stigmatising the school regime as oppressive were signed by several hundred pupils at most major classical high schools in the city and its outskirts. For example, classical high schools had their own lock-ups (kartsery), and the behaviour of pupils was policed outside school hours - they could be subject to disciplinary action not just for smoking in the streets, but also for visiting cafés, music-halls, etc. For some documents relating to surveillance in the classical high schools, see: Gorodok v tabakerke. Vol. 1.

${ }^{60}$ For the fees, see: Spravochnaia knizhka Tenishevskogo Uchilishcha. Izdanie Tenishevskogo Uchilishcha. Petrograd, 1915. P. 16: the amount charged was 200 roubles per semester in the preparatory classes, 325 roubles per semester in the junior classes, and 360 roubles a semester in the senior classes - as opposed to the 40 roubles per semester charged in the state institutions.

${ }^{61}$ Rossiiskii gosudarstvennyi istoricheskii arkhiv, St. Petersburg (RGIA). F 25. Op. 2. D. 855. L. 1.

62 RGIA. F. 25. Op. 2. D. 855. L. 2-12.

63 Svedeniia o kolichestve uchashchikhsia v Chastnom Kommercheskom Uchilishche M. Shidlovskoi // RGIA. F.25. Op. 2. D. 855. L. 69. 
schools to have as many as 40 pupils, these figures were highly unusual, and in crude commercial terms, made little sense: in fact, in the first two years that the school was in operation, Shidlovskaya was subsidising the costs quite heavily out of her own money ${ }^{64}$.

This painful situation was partly the result of the fact that the Ministry of Trade and Industry did not accord Shidlovskaya's Commercial College the same rights as its own commercial colleges (and in particular, the right to matriculate its pupils into institutions of higher education) until $1912^{65}$. But it was also the result of the extremely ambitious character of the equipment and education. Both the school's first premises, on Manezhnyi pereulok, and at no. 7 ulitsa Shpalernaya, to which it moved in September 1913, were "clean and light", and the latter also "spacious" (a sign that by this stage, the school had managed to expand its intake of pupils). They were also located in the most prestigious area of the city: in the first case, a stone's throw from the elegant end of Nevsky Prospect, and in the second, close to the Summer Garden and the aptly named Millionnaya ulitsa, the local "Millionaire's Row", as well as the palaces and mansions of the French Embankment (now Kutuzov Embankment) and the Winter Palace Embankment ${ }^{66}$. Among the teaching aids, as well as a globe, maps, wall-charts, an abacus and other relatively standard items, were a magic lantern operated by electricity, stereoscopes with special slides, a microscope, and a special room for handcrafts fitted with seven benches and lathes, and a full set of carpentry equipment. Care was taken to provide the pupils with nutritious meals, to organise regular medical inspections and to take them on excursions, such as skiing trips to Jukka in the outskirts of St. Petersburg; "in autumn and spring they play foot-ball [sic!] under the supervision of the gymnastics teacher" 67 .

This emphasis on health and gymnastics was pervasive. In fact, while the school's statutes might dutifully list the subjects required by the Ministry of Trade and Industry's model programmes (including "commercial arithmetic, book-keeping, political economy, jurisprudence, technology"), the timetables told a rather different story. While some subjects on the official list were also listed on the records kept by the school (for instance, German, French, mathematics in its various forms, science, and Russian language), the in-house records also included "nature study" and "modelling" as well as handicrafts and drawing ${ }^{68}$. Music was not listed in the school's statutes, but figured in the timetables as submitted to the Ministry of Trade and Industry, and on 29 September 1911, Leonid Leonidovich Lisovsky, then teaching singing in the St. Petersburg Commercial College, was engaged to teach the subject to pupils in Shidlovskaya's school ${ }^{69}$. Conversely, in 1915,

${ }^{64}$ Dokladnaia zapiska i. o. direktora S. Sozonova // RGIA. F. 25. Op. 2. D. 855. L. 24 ob.

65 RGIA. F. 25. Op.2. D. 855. L 9; 1. 46.

${ }^{66}$ For the premises on Manezhnyi, see: RGIA. F. 25. Op. 2. D. 855. L 24 (consisting of 5 rooms, the place is described as "fairly spacious"); for those on Shpalernaya: RGIA. F. 25. Op. 2. D. 855. D. 360. L. 2. The school occupied an entire two floors of the building at no. 7 Shpalernaya.

67 RGIA. F. 25. Op. 2. D. 855. L. 24-24 ob. (sports), 1. 29 (equipment).

${ }^{68}$ Compare RGIA. F.25. Op.2. D. 855. L. 12 ob. -13 (for the list of subjects in the statutes, which resembles those offered in other commercial colleges: see, for instance, Spravochnaya knizhka Tenishevskogo Uchilishcha.

${ }^{69}$ RGIA. F. 25. Op.2. D. 857. L. 4 (appointment of Lisovsky). For the non-mention in the statutes, see RGIA. F. 25. Op. 2. D. 855. L. 12 ob. - 13; for the timetables, see ibid., ll. 6-7 and 1l.26-7. In the draft timetables (ll. 6-7) it was proposed that singing was taught to pupils at all levels, while in the completed timetables (1l.26-7) it figured only for the preparatory classes, which may mean either that it proved in practice difficult to secure enough hours of teaching to cover the entire span of ages, or that ministerial regulations assumed singing would be taught only to younger age groups. It appears from Lossky's memoirs 
the Ministry of Trade and Industry felt compelled to investigate whether the school was bothering to teach Religious Knowledge, a subject then compulsory in all schools in the Russian Empire, which may perhaps have been an indication of slackness about observing the rules ${ }^{70}$.

In fact, there was overall a whiff of "free education" about the Shidlovskaya school, well before it was actually taken over by the Society for Free Education, on 30 April $1918^{71}$.

The emphasis on games, learning through labour, and creativity were all characteristic of reformist pedagogy of the time ${ }^{72}$. Among members of staff recruited to teach at the Shidlovskaya College in its early stages were, alongside more conventional specialists in Russian language and literature, history, and mathematics, Yuliya Ivanovna Fausek, a graduate in biology of the Women's Higher Courses of Education (offering the equivalent of a university-level training to those excluded from actual universities by sex), and Ivan Ivanovich Sidorov, also a scientist (in his case, a product of St. Petersburg's famous Faculty of Physics and Mathematics) ${ }^{73}$. Fausek, a pioneer of Maria Montessori's methods of nursery education in Russia, recalled in 1924 that L. O. Pettsel', the director of the Froebel Kindergarten at the First Pedagogical Institute in St. Petersburg, had demonstrated Montessori's methods at the Shidlovskaya College in September 1913; in October, she herself had, "with the warmest support from the school's owner M. A. Shidlovskaya", initiated a kindergarten attached to the school ${ }^{74}$. The school was given official permission to open by the Education Ministry on 15 August $1914^{75}$. The spirit of Montessori teaching, with its emphasis on individual development, the value of practical skills and education for labour, and simple, down-to-earth occupations and tasks, evidently fitted well with the ethos of the Shidlovskaya College's teaching of older children ${ }^{76}$. In the late 1910s, Ivan Sidorov himself spent time making wooden toys for the Montessori kindergarten, a most unusual activity for the holder of the position of school inspector, whose official duties ran more to supervision of the social order and good behaviour in his home institution ${ }^{77}$.

The School's position was helped by the general attitude to commercial colleges, which had developed rapidly after a decree of 1896 from the Ministry of Trade and Industry resolving to expand this type of educational establishment. The Ministry's attitude to the schools under its care seems to have been decidedly liberal, compared with the Education Ministry, and the level of regulation was light, which encouraged experimentation.

(Nasha sem'ya) that music actually played a significant part in the activities of the Shidlovskaia College at all levels.

${ }^{70}$ RGIA. F. 25. Op. 2. D. 855. L. 51. Lossky recalls that there was a priest who taught at the school in his day, a roaring snob who did not tolerate the boys who were not of noble birth (Nasha sem'ia. P. 155).

${ }^{71}$ For the transfer to this Society, whose statutes ordained that its purpose was to "foster the allround dissemination and enactment in life of the rational principles of free education, and above all the principles of labour education and social education on the basis of freedom, and of correct application of pupils' physical development", see RGIA. F.25. Op. 2. D. 858. L.3-4. Khentova, mentions the transfer, but with characteristic lack of meticulousness refers to it as "after 1917". Khentova S. M. Shostakovich: zhizn'. Vol. 1. P.75,

72 See the journal Svobodnoe vospitanie, founded in 1907.

73 RGIA. F. 25. Op. 2. D. 856. L. 3 (Sidorov); RGIA. F. 25. Op. 2. D. 857. L. 1 (Fausek).

${ }^{74}$ Fausek Yu.I. Metod Montessori v Rossii. Peterburg [sic!] 1924. P. 5.

75 RGIA. F. 25. Op. 2. D. 855. L. 49.

76 For a description of Montessori teaching as interpreted in the Shidlovskaya School's kindergarten (known, following Montessori, as the "House of Children"), see: Fausek Yu. I. Metod Montessori...

77 On toys, see: Fausek Yu. I. Metod Montessori...; on duties, see: Ustav Chastnogo vos'miklassovogo kommercheskogo uchilishcha M. A. Shidlovskoi (1910) // RGIA. F. 25. Op. 2. D. 855. L 15. 
Unfortunately, early twentieth-century Russian progressive pedagogy's gain is the historian's loss. The classical high schools generated mountains of paperwork, since the Education Ministry demanded detailed reports on the progress and character of the pupils. The hundreds of bulging files relating to these schools in the archives are in sharp contrast to the bare half-dozen folders containing a total of perhaps 100 sheets on the Shidlovskaya school's years of operation ${ }^{78}$. Certainly, the documentation makes it possible to say that the school had once more run into financial trouble by the spring of 1918 (despite being nationalised in February that year; these money worries were one factor behind the takeover by the Society for Free Education $)^{79}$. The amalgamation of different schools in order to produce "United Schools of Labour" (the required type after the reform of the education system by government decree on 16 October 1918) generated other problems also. By January 1919, Sidorov (returned from a period as a POW after serving at the Front in the First World War) was appealing to the People's Commissariat of Education for the transfer of more pupils, particularly girls, to the top classes ${ }^{80}$. By May, there were severe problems with staff numbers, and Sidorov was pleading with the Military Commissariat not to force any more teachers into conscription ${ }^{81}$. Judging by the absence of any more documentation, these efforts were unsuccessful, and the existence of what was then called "the United School of Labour of Free Socialisation and Education" came to an end in early summer $1919^{82}$. Thus, the documentary record supports Shostakovich's own claim in his autobiography that he left the school when it closed down in 1919.

The limited amount of information available makes the issue of what was actually taught at the Shidlovskaya College partly a question of surmise. But Lossky's detailed memoir confirms the "free school in sheep's clothing" analysis. For instance, in the statutes, it was specified that the pupils wore the standard uniform of Ministry of Trade and Industry schools; Lossky records that they actually wore cloth overalls and sailor suits ${ }^{83}$. (In the beautiful drawing of Shostakovich by the artist Boris Kustodiev, Shostakovich is shown wearing a sailor top, likely part of the uniform, since, as Lossky records, the young Mitya had got to know Kustodiev through his son, who was a pupil at the Shidlovskaya College.) Creative education was definitely a feature: for example, in 1917, as Lossky remembered, the pupils gave a performance of Blok's The Pussy Willow, with choral and solo sections, and then "we second-formers acted out, to the narration of Volodya Bogdanovich, Nekrasov's lyric-dramatic poem A Clear Morning, with me as the harshly rational fishermen, and the two rude little boys, for some reason, played by two little girls" 84 .

The Lossky connection may well also explain why Shostakovich was sent to the Shidlovskaya College. According to Khentova's biography, Shidlovskaya's husband was a me-

${ }^{78}$ Far better documented is the childhood of Igor Stravinsky, on which see: Kelly C. Memory and Truth: Stravinsky's Childhood (1882-1901) // Stravinsky in Context / ed. by G. Griffiths. Cambridge, 2019 (forthcoming).

${ }^{79}$ On the nationalisation, see: RGIA. F.25. Op.2. D. 860. L. 1; on the Society's takeover, RGIA. F. 25. Op.2. D. 858. L.2.

80 RGIA. F.25. Op. 2. D. 858. L. 18.

81 RGIA. F.25. Op.2. D. 860. L. 8.

${ }^{82}$ It is sometimes claimed (e.g. Khentova S. M. Shostakovich...; Wilson E. Shostakovich: A Life...) that the Shidlovskaia College was renamed the "United School of Labour no. 108", but the school files make no reference to that title.

${ }^{83}$ Lossky B. Nasha sem'ya... P. 150.

${ }^{84}$ Ibid. P. 169. 
trologist, and hence a professional colleague of Shostakovich's father ${ }^{85}$. This appears to be only partly accurate. Ivan Sidorov, the science teacher and later director of the Shidlovskaya College, to whom Shidlovskaya was married in 1912 or 1913, was, in his pre-pedagogical professional life, a specialist in the measurement of atmospheric pressure (pribory davleniya), but he had switched to teaching several years before Dmitry Shostakovich went to the College. It seems much more likely that the Shostakoviches were recommended to Shidlovskaya by the Losskys, whose son Boris was two years older than Dmitry, and had therefore begun attending her school in 1913 or 1914.

There was likely reason for Khentova to equivocate. By the time that she was writing, "free education" was an inflammatory term in Soviet culture (it had fallen out of favour with the return to traditional educational skills in 1932, and Shostakovich was, in later autobiographical statements, to refer to his schooling only in the sparsest detail). The eschewal of Shidlovskaya's married name was also no doubt deliberate. In 1925, Shidlovskaya, under the name Sidorova, was arrested and sent to the Solovki labour camp, along with the other members of the St Sergius Cathedral parish council (literally, "group of twenty", dvadtsatka). There was also the opposite of an incentive to refer to the Shostakoviches' friendship with the Losskys, since the family, having been forced into emigration during the Philosophy Steamer incident of 1922, was contaminated by the stain of "desertion of the motherland" as well as repression ${ }^{86}$. Even if Khentova had been the kind of careful positivist who was in principle committed to retrieving facts from archives (in fact, her standard source for her many and repetitive works on the composer's life was what could politely be called "oral history", or less diplomatically, hearsay and gossip), she would hardly have been encouraged to dig deep in the story of Shostakovich's education.

That said, when it comes to the effects of Shostakovich's education on him personally, any writer is forced to speculate. The written record could not, even if it were more substantial, finally settle the issue of how his schooling affected his personality, attitudes, and aesthetic principles. But he certainly spent longer at the Shidlovskaya College than any other educational establishment, with the possible exception of the conservatoire. He began attending it no later than 1915, when he would have been the right age for the junior preparatory class. But one might also wonder whether he attended the Montessori kindergarten in earlier years as well. At nearly 7 in September 1913, he would have been just the right age. Whichever way, he attended the school at a point when Montessori methods, with their emphasis on respect for children's individual abilities, and development of their artistic potential, but also on the need for self-discipline - imposed by the assignation of regular work-tasks and by the instigation of sessions of silence - already enthused Shidlovskaya and her husband. He may have taken part in the movement to music activities that were another regular part of the programme. It is entertaining to note that a little book published by Fausek and Shidlovskaya (as Sidorova) in 1923, What We Do at Our School, which portrayed in coloured illustrations the activities at a Montessori

${ }^{85}$ Khentova S. M. Shostakovich: zhizn'. Vol. 1. P. 75.

86 See the annotations by Sof'ya Nuridzhanova to her publication of a diary written by her twin sister Yuliya Krivulina (née Khordikainen, 1928) in 1940-1945. The Khordikainen sisters were taught French and Catholic religious knowledge by Mariya Shidlovskaya-Sidorova, and the publication of the diary contains valuable biographical material about her: Dnevnik Lyusi [Yulii] Khordikainen / ed. by S. Nuridzhanova // A.I.Zalessky. Zhizn' v okkupatsii i v pervye poslevoennye gody: Pushkin - Gatchina - Estonii. St. Petersburg, 2011. URL: http://www.molodguard.ru/heroes1609.htm (accessed 20.04. 2013). I would like to thank Aleksandr Liarsky for this reference. 
nursery school, includes a plate bearing the legend, "And then we moved to music. Mitya beat the drum" 87 .

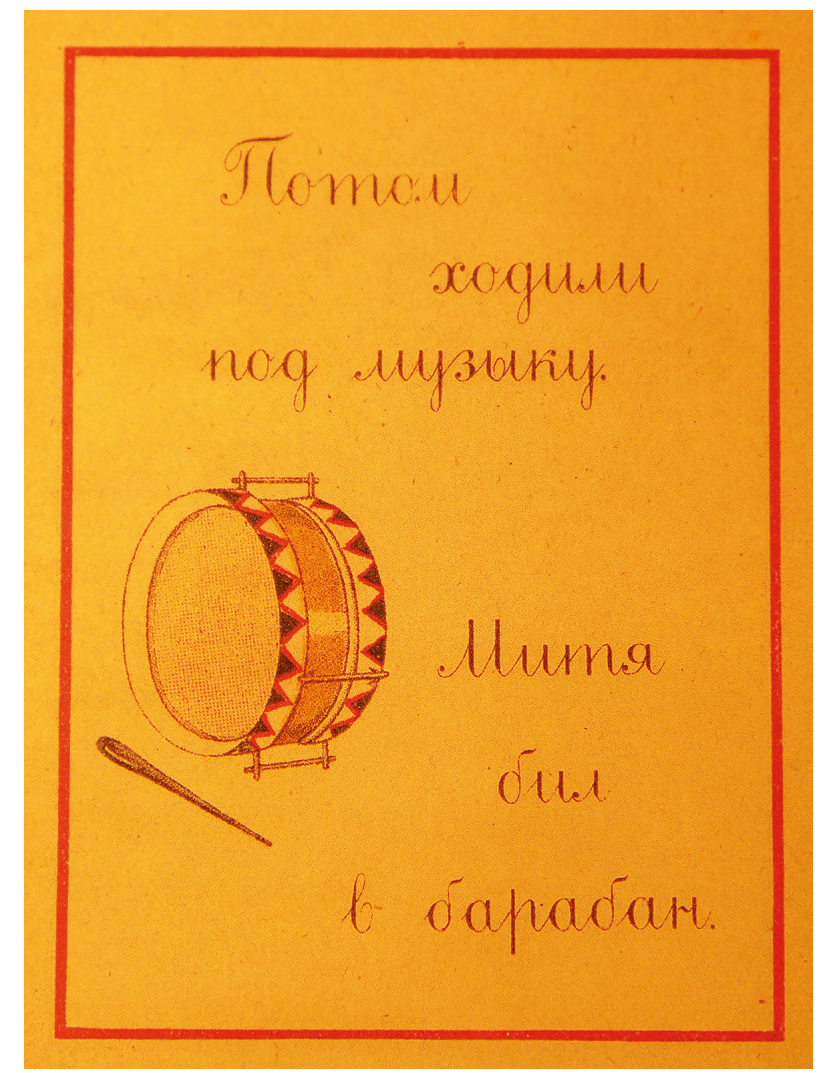

"Then we moved to music. Mitya beat the drum" (ill. to the book of Yuliya Fausek and Mariya Sidorova (Shidlovskaya) "What We Do", 1923)

Were Fausek and Shidlovskaya paying tribute to the pupil who had most strikingly borne out the value of arts education at a young age? Certainly, Shostakovich himself seems to have felt grateful to Shidlovskaya. Anna Sidorova, the latter's daughter (b. 1913), recalled that Shostakovich visited her mother in 1940, "and stayed there for quite a while; they had lunch. He wrote regularly to Mama right up until her death" in $1949^{88}$.

There was a dramatic difference between the teaching that Shostakovich received at the Shidlovskaya College and the pedagogical style preferred by Glyasser, who, as Lossky put it, was exceptionally dictatorial and rigid: study with him "was far from always enjoyable, given the teacher's cross and impatient attitudes to his pupils" ${ }^{89}$. Equally, the Petrograd conservatoire was in many respects a traditional institution, which saw fewer changes than most institutions of Russian higher education at the period. It is clear from

${ }^{87}$ Fausek Yu., Sidorova (=Shidlovskaya) M. Kak my zanimaemsia (Petrograd, 1923). See also fig.

${ }^{88}$ Reported by Nuridzhanova in the annotations to Dnevnik Lyusi Khordikainen.

${ }^{89}$ Lossky B. Nasha sem'ya. P. 185. 
the biographies in the recent collection edited by Marina Frolova-Walker and Jonathan Walker, Music and Soviet Power, that many teachers both at the Moscow and at the Leningrad conservatoires remained in their posts for decades, with 1917 making little, if any, difference.

The contrast between the relatively free-and-easy learning of his early years and the pressures at the conservatoire emerges in one of Shostakovich's answers to Gruber's questionnaire in 1927:

"While I was doing the course in Theory of Composition at the Conservatoire, I saw it as a 'necessary evil', and submitted more or less passively. Once I had finished it, though, I began to sense the impossibility of composing freely and unmediatedly. I ended up having to squeeze out' a whole series of compositions (in summer 1925, a symphony, two movements of a string octet...); from autumn 1925 to December 1926, I kept trying to compose, but it kept not working out (at first, after I left the conservatoire, I'd become a 'professional' in too narrow a sense, placing technical proficiency above anything else; I involuntarily strove to make everything turn out sounding 'correct' and smooth); my creative consciousness could not escape from the framework that the canons of my education had imposed on me"90.

The tension between "academic canons" and the view that it was important to "compose freely, spontaneously" makes clear the very different educational perspectives that had shaped Shostakovich's experience. Attention to the impact of politics in a narrow sense on the composer's development should not lead us to ignore the other significant, and highly contradictory, cultural influences that shaped his life.

\section{Some Conclusions}

As I have argued here, the term "Marxism-Leninism" is largely irrelevant to the interpretation of Shostakovich's work. The term is of late origin (end of the 1930s), and does not well reflect the unformalised "leftism" to which he appears to have gravitated in the 1920s. Arguments that Shostakovich had an "unpolitical" attitude at this period beg the question of whether it was possible not to be "political" at this era, when no position was seen as "beyond politics" by the participants. Even the flood that devastated Leningrad in the autumn of 1924, as the art critic Nikolai Punin recorded in his diaries, was seen by some as a political event. Shostakovich's 1933 comment "When someone writes that the oboe and clarinet in some symphony represent Soviet civil servants, and the brass stands for Red Army soldiers, you want to shout, 'Not true!' is characteristic of the times in its reductio ad absurdum: the protest against the simple-minded decoding of artistic signals was not necessarily a plea for the total depoliticisation of art"91. Typical of the times, too, was the "modern" tenor of the composer's life in the 1920s, with the experiments in free love that characterised the time of his first marriage.

At the same time, Shostakovich's early enthusiasm for "left arts" was, the indications are, more the product of gut feeling than of intellectual reflection. There was every reason for someone of his age to be caught up in the initial excitement and fervour of political revolution, as the composition of the early piano works Hymn to Freedom, and a Funeral

90 Anketa po psikhologii... P. 472.

${ }^{91}$ See Shostakovich's comments on: Gorodinsky V.M. K voprosu o sotsialisticheskom realizme v muzyke // Sovietskaia muzyka. 1933. N 1. P.120-121. 
March for Victims of the Revolution confirms. At the same time, the pairing of the "Hymn to Freedom" and "Funeral March" already indicated ambivalence with regard to the heritage of revolution. The double-vision was no doubt enhanced by the fact that the composer saw his share of privation: if, according to Shteinberg's diaries, the Shostakovich household was well-off enough even in 1922 to allow his mother to make gifts of patisseries at holiday time (i.e. significantly above the breadline), that same year witnessed the premature death of Shostakovich's father. Shostakovich himself was to emphasise, in his autobiography of 1926, the privation that he had experienced, and the hack-work (khaltura) as a pianist for silent movie showings to which he had been consigned by this ${ }^{92}$. Certainly, the hardship in which this plunged his family did not impede the creative energy and basic optimism that characterised his outlook at the time, but the after-effects may have been felt in the long term. The widespread pattern recorded in the 1924 Zemgor essays, whereby child witnesses of the historical cataclysm of revolution simply did not understand what was going on could be followed, as some of the witnesses also recorded, by a demoralizing and energy-sapping reaction, what would now be understood as "post-traumatic syndrome".

The revolution no doubt seemed to Shostakovich, as to many of his contemporaries, at once invigorating and threatening. The uncertainty of the times fostered both ambition and a sense of vulnerability. If the supremely energetic creative period that took hold in the early 1920s was certainly one of the effects of Shostakovich's divided and disrupted childhood, the persistent anxieties about his own fragility in both a physical and a creative sense that afflicted the composer in his later years must surely have been another.

\section{References}

Akopyan L. O. Dmitry Shostakovich: fenomenologiya tvorchestva. St. Petersburg, RAN, Ministerstvo kul'tury Rossiiskoi Federatsii, Gosudarstvennyi institut iskusstvoznaniia Publ., 2004, 500 p. (In Russian)

Alekseeva L. The Thaw Generation: Coming of Age in the Post-Stalin Era. Transl. by P.Goldberg. Boston Little, Brown Publ., 1990, 339 p.

Chukovskaya L. Zapiski ob Anne Akhmatovoi. Vol. 1. St. Petersburg, Neva Publ., 1996, 836 p. (In Russian)

Coles R. The Political Life of Children. Boston, Atlantic Monthly Press, 1986, 352 p.

Corney F. Telling October. Memory and the Making of the Bolshevik Revolution. Ithaca, Cornell University Press, 2004, $301 \mathrm{p}$.

Danilevich L. Dmitry Shostakovich: zhizn' i tvorchestvo. Moscow, Sovetskii kompozitor Publ., 1980, 300 p. (In Russian)

Fairclough P. Shostakovich's Fourth Symphony: Context and Analysis. PhD Thesis, University of Manchester, 2002, 300 p.

Fay L. Shostakovich: A Life. New York, Oxford University Press, 2005, 488 p.

Fay L. Shostakovich and His World. Princeton, Princeton University Press, 2004, 432 p.

Fay L. Shostakovich Versus Volkov: Whose “Testimony"? Russian Review, 1980, vol. 39, pp. 484-493.

Gasparov B. Five Operas and a Symphony: Word and Music in Russian Culture. New Haven, Yale University Press, 2005, $304 \mathrm{p}$.

Fitzpatrick S. The Lady Macbeth Affair. Fitzpatrick S. The Cultural Front: Power and Culture in Revolutionary Russia. Ithaca, Cornell University Press, 1992, pp. 183-215.

Fitzpatrick S. Voldemort or Stalin? London Review of Books, 2011, vol.33, no. 23, 1 December, pp. 34-35.

Hellbeck J. Revolution on My Mind: Writing a Diary under Stalin. Cambridge (MA), Harvard University Press, 2006, $448 \mathrm{p}$.

Kelly C. Children's World: Growing Up in Russia, 1890-1991. New Haven, Yale University Press, 2007, 714 p.

Kelly C. "The Lads Indulged Themselves: They Used to Smoke": Tobacco and Children's Culture in Twentieth-Century Russia. Tobacco in Russian History and Culture: From the Seventeenth Century to the Present. Eds M. P. Romaniello, T. Starks. New York, Routledge, 2009, pp. 158-182.

92 Zhiznopisanie Dmitriya Dmitrievicha Shostakovicha (16 June 1926, Leningrad) // DSPD. P. 469. 
Kelly C. Kak sdelany vospominaniia: deti i lichnoe proshloe v Rossii nachala XX veka. Istoricheskaia pamyat'i obshchestvo v Rossiiskoi imperii i Sovetskom Soyuze (konets XIX - nachalo XX veka). Mezhdunardonyi kollokvium. Nauchnye doklady. St. Petersburg, Evropeiskii dom Publ., 2007. (In Russian)

Kelly C. Memory and Truth: Stravinsky's Childhood (1882-1901). Stravinsky in Context. Ed. by G. Griffiths. Cambridge, Cambridge University Press, 2019 (forthcoming).

Kharkhordin O. The Collective and the Individual in Soviet Culture. Berkeley, University of California Press, 1999, $406 \mathrm{p}$.

Kozlova N. Sovetskie lyudi: stseny iz istorii. Moscow, Evropa Publ., 2005, 544 p. (In Russian)

Lahusen T. How Life Writes the Book: Real Socialism and Socialist Realism in Stalin's Russia. Ithaca, Cornell University Press, 1997, 247 p.

Lesser W. Music for Silenced Voices: Shostakovich and His Fifteen Quartets. New Haven, Yale University Press, 2011, $368 \mathrm{p}$.

MacDonald I. The New Shostakovich. London, Fourth Estate, 1990, 339 p.

Mende W. Musik und Kunst in der sowjetischen Revolutionskultur. Köln, Böhlau Publ., 2009, 644 S.

Polotskaya N., Dokunin V. Redkollegiya stennoi gazety i kruzhok rabkorov. Moscow, Pravda Publ., 1928, 153 p. (In Russian)

Schmidl S. Oper in der "Traumfabrik Kommunismus": Zum Musiktheater im sozialistischen Ost- und Südeuropa der Stalinära. Österreichische Muzikzeitschrift, 2012, Bd. 67, no. 7, S. 31-39.

Schostakowitsch-Aspekte: Analysen und Studien. Hrsg. von D. Redepenning, K. Meyer. Berlin, Verlag Ernst Kuhn Publ. 2014, 389 S.

Utekhin I. Ustnye rasskazy o blokadnom opyte: svidetel'stva raznykh pokolenii. Antropologicheskii forum, 2006, no. 5, pp. 325-344. (In Russian)

Yerushalmi Y. Zakhor: Jewish History and Jewish Memory. Seattle, University of Washington Press, 1982, $191 \mathrm{p}$.

Zubok V. Zhivago's Children: The Last Russian Intelligentsia. Cambridge (MA), Harvard University Press, $2009,453 \mathrm{p}$.

Received: February 21, 2018

Accepted: September 10, 2018 